УДК $338.481(438-25-2)$

\title{
TOURISM ATTRACTIVENESS OF STASZÓW ACCORDING TO ITS RESIDENTS
}

\author{
A. Zieliński \\ Department of Paleogeography, Geoecology and Nature Protection \\ Jan Kochanowski University in Kielce \\ Kielce, Poland
}

\begin{abstract}
In the work, the assessment of tourism attractiveness of a small, 17-thousand county town of Staszów has been conducted. The town is located in the south-eastern part of Świętokrzystkie Voivodeship, in the area of Połaniecka Basin, which constitutes the subregion of Nidziańska Basin. The analysis has been based on the anonymous survey research of the representative group of local residents.

Until recently, the region was not perceived as attractive for tourists. Nevertheless, it has some potential in this field. There are various natural peculiarities, which condition karst phenomena. Unfortunately, only few assets of the natural environment in the above mentioned region are properly valued by its local residents and are professionally promoted.

Keywords: tourism attractiveness, Staszów, karst lakes, karst, Nidziańska Basin
\end{abstract}

\section{Introduction:}

Staszów is a small, 17-thousand county town, located in the north-eastern part of Nidziańska Basin (pic.1 ). In terms of administrative characteristics, it is situated in the south-eastern part of Świętokrzystkie Voivodeship, which natural value is characterised by geographers above average (Zieliński 2007 a). Although Staszów and its surrounding area possesses a unique landscape, it has generally not been associated with being valuable in terms of tourism. It has rather been perceived as having industrial and service character. For many years, this profile has been emphasized and consolidated by a sulphur mine in Grzybów, in the close proximity to Staszów, as well as currently operating power station in Połaniec (Zieliński 2010 c).

Nevertheless, a dense forest complex, called Golejowskie Forest, has been preserved close to the town. The area is characterised by a unique feature - a large cluster of small lakes. Their presence in the belt of the Polish uplands is not a frequent phenomenon. Moreover, an exceptionally numerous group of natural water bodies is connected with a specific geological structure, which conditions the occurrence of karst phenomena, which added to the formation of particular features and significantly emphasized geodiversity and increased biodiversity. (Zieliński 2007 b, 2010 a, b, 2011 b). 


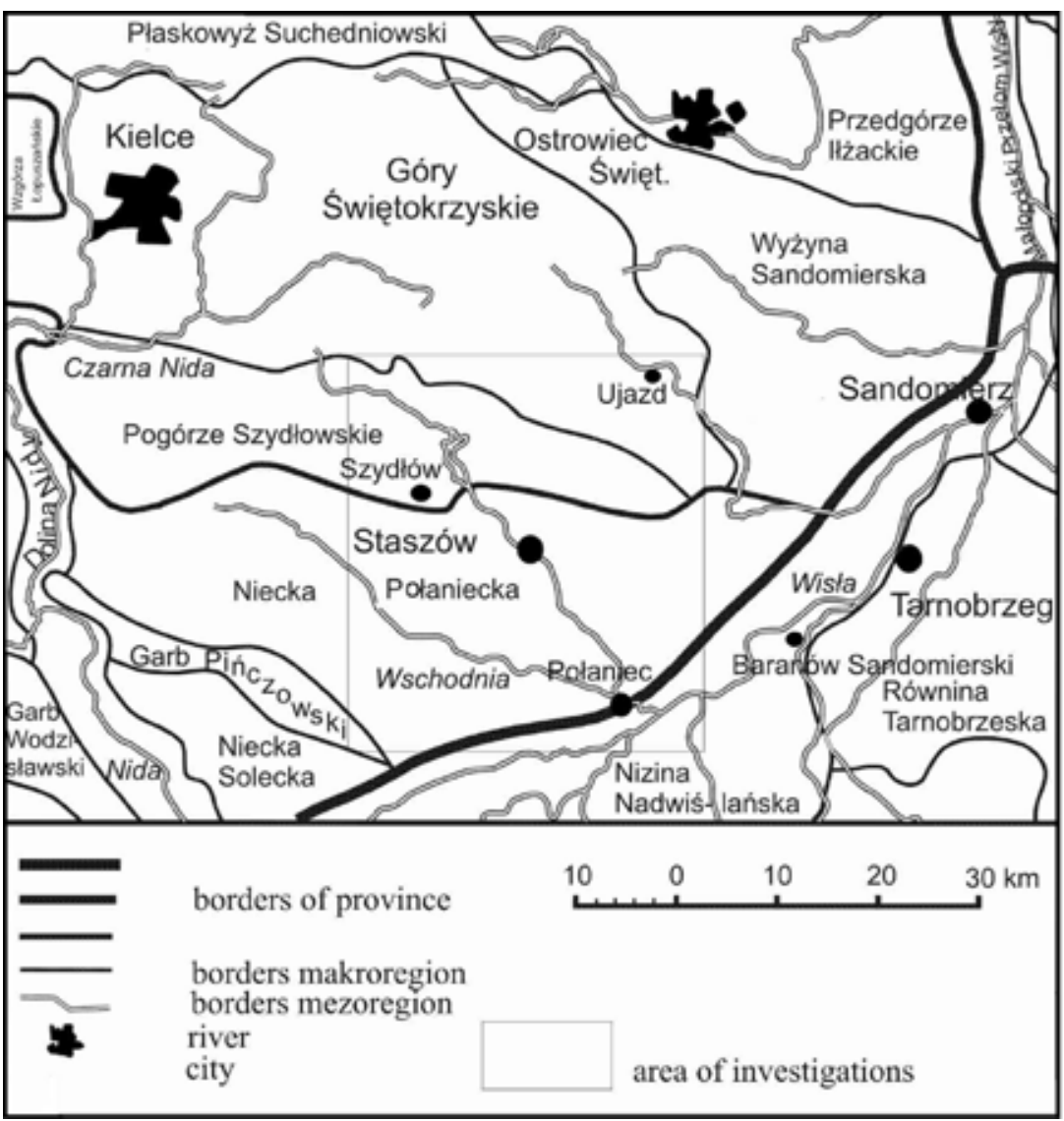

Pic 1. The location of Staszów against the background of physio-geographic units according to Kondracki (1994).

\section{Methods and aims of study}

In 2011, a survey was conducted in the town of Staszów. 152 local residents took part in it. 67 of them were the employees of the Town and Province Hall in Staszów, Staszów Forest District Office and the District Office. The rest of the survey participants were not professionally connected with the public administration sector. However, it is worth mentioning that a considerable percentage of the respondents work in the sector of tourism services or in the sectors closely connected with tourism. Therefore, their assessment of the town's attractiveness in terms of tourism may have a significant influence on the development of tourism in the area. The research was anonymous.

The aim of the work was to obtain information about the attractiveness of the town and its surrounding areas according to the local residents. It is well known that a positive attitude of local residents is of great value when it comes to the formation of a tourist product and its quality. (Niezgoda 2011). A positive opinion of local residents on the tourist attractions may considerably strengthen and support its perception by tourists. Moreover, by being hospitable, 
having a positive attitude towards tourists and creating familiar environment, the residents can form appropriate atmosphere for the development of tourism in the region. What is more, tourism should also be perceived as a magnificent prospect for creating new work places, for some people being their only source of income, for some the additional one. Finally, local residents may be perceived as a unique value of the region, considerably influencing its attractiveness. On the other hand, satisfaction of the inhabitants may significantly affect tourists' impressions. It is well known that satisfied and positively thinking people establish new contacts more easily and more willingly as well as provide information and assistance to tourists with the same approach (Niezgoda 2011).

\section{The results}

1. Tourism attractiveness of the town and its surrounding areas.

The results of the research indicate that, basically, local residents assess the general attractiveness of Staszów and its surrounding areas as "sufficient" 43\% and "good" $37 \%$. A "very good" mark was given only by $9 \%$, whereas "not satisfactory" by $8 \%$. It is worth mentioning that much better assessment was given by the employees of the local administration. In this group of the respondents, a "very good" mark was given by $14 \%$. The workers of the District Office gave the most favourable marks $-17 \%$ gave a "very good" one. $41 \%$ of all the office workers assessed the town and its surrounding areas as "good" and 39\% "sufficient". Only $6 \%$ of the respondents in this group decided to give a "not satisfactory" mark.

Generally, the respondents provided positive assessment of their marks, drawing special attention to the natural values of the Staszów region, particularly to the forest areas with lakes (ph. 1 i 2) with the nearby Chańcza lake (40\% of the respondents). Moreover, $30 \%$ of the researched people emphasized the attractiveness connected with the existence of interesting towns with monuments. $10 \%$ of the respondents drew attention to a picturesque landscape. They also mentioned good location of the region as a base for further exploration $(5 \%)$.

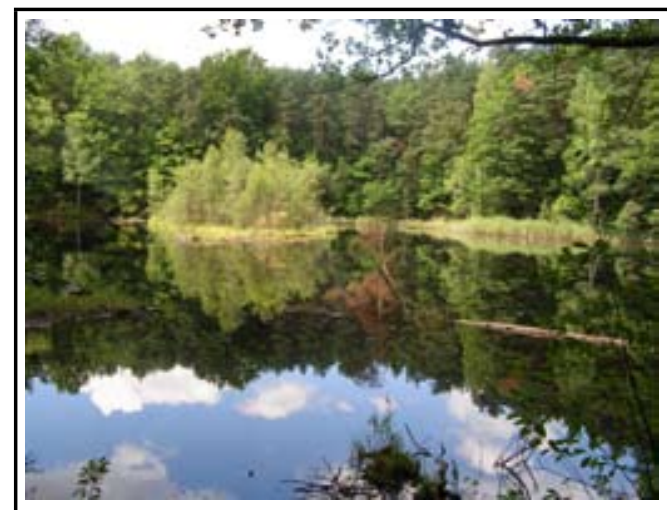

Ph.1. Donica mid-forest lake with a floating and moving peat island (ph. Artur Zieliński).

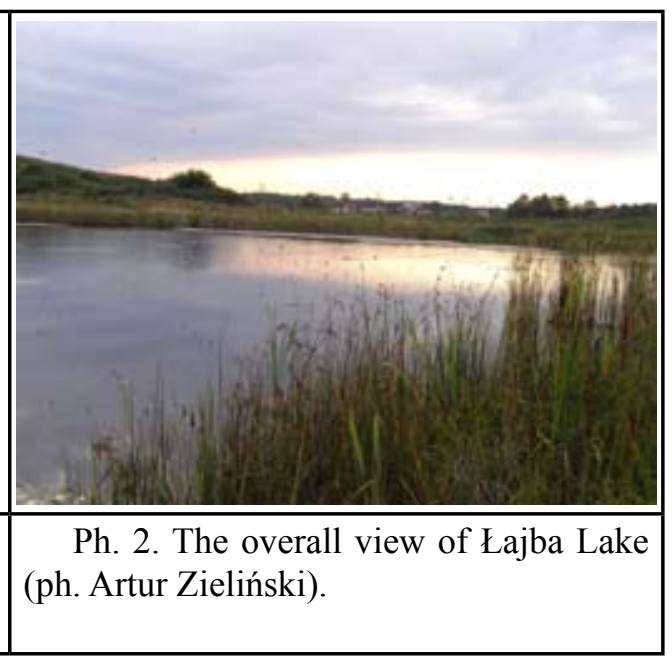


However, a low assessment was explained with the examples of neglected places $(30 \%)$, poor tourist infrastructure $(20 \%)$, poor general tourist information $(17 \%)$. The town's insufficient cultural offer was also emphasized, which could add variety to the tourists' stay in the region (15\%). As much as $12 \%$ of the local residents justified their totally negative assessment with the lack of interesting places.

However, among the greatest assets of the town and its surrounding areas, Golejowskie Lakes (37\%) and Chańcza Lake (19\%) were pointed.

According to the respondents, the most interesting town in the analysed area was Kurozwęki (22\%). The palace complex in the town has become a tourist attraction of supraregional importance (Zieliński 2012). Other towns indicated in the survey were Szydłów (11\%), Rytwiany(9\%) and Staszów (8\%). In Staszów, the only interesting places mentioned were the Church of St. Bartłomiej and the Town Hall with the town square (ph.3 and 4).

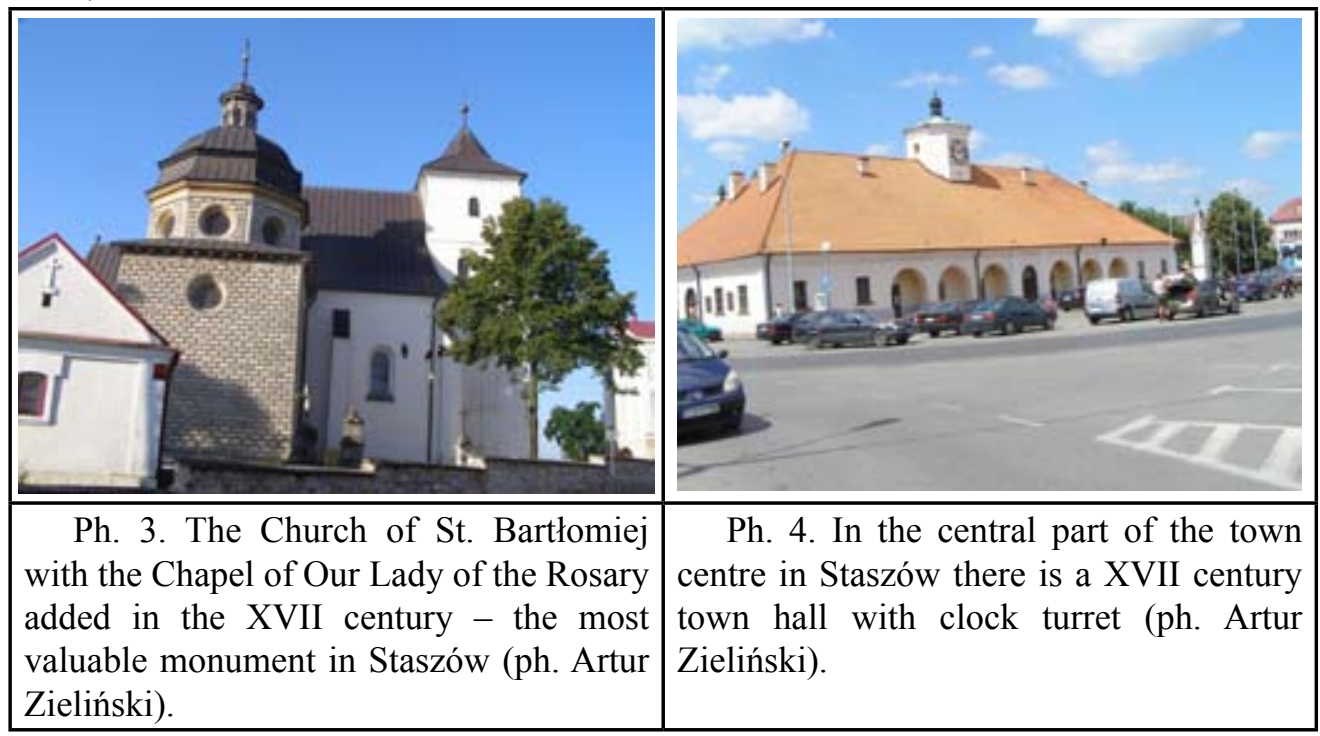

The question of "What attracts tourists to the Staszów region?" was mostly answered by indicating mainly natural assets of the area, especially Golejowskie Forests with lakes and Chańcza Lake. A considerable number of respondents said that the main incentive for them to visit the region was the interest in seeing American buffalos in the palace complex in Kurozwęki. They also drew attention to the fact that prices in the Staszów region were low and therefore, competitive. Moreover, they pointed out quietness of the described place. Generally, the answers coincided in many respects with the assets of the region mentioned previously.

\section{Assessment of Staszów tourist infrastructure}

In terms of the town's adaptation to receive tourist, local residents basically consider the accommodation to be sufficient in amount ( $40 \%$ ). However 35\% think that it is not satisfactory. $25 \%$ of the respondents had no opinion on the subject, which is not strange, as 
local residents do not take advantage of the tourist accommodation. The accommodation base in Staszów is more favourably assessed by employees of the Town and Province Hall in Staszów, as well as the District Office. $46 \%$ of the group think that the accommodation is sufficient, $24 \%$ consider it not satisfactory. In this group, the percentage of respondents who did not present any opinion on the subject was $30 \%$.

Communication in Staszów was considered satisfactory (56\%) and not satisfactory by $25 \%$. Only $17 \%$ consider transport as good, and $2 \%$ as very good.

The quality of roads is generally valued as satisfactory (45\%) and good (28\%). As much as $27 \%$ of the respondents consider the quality of roads as not satisfactory. The lack of very good marks should not surprise anyone. The large proportion of not satisfactory marks is connected with long-standing negligence. Especially painful negative assessment is directed towards the quality of the access road to Golejowskie Lakes as well as the dreadful condition of the surface on the road from Staszów to Sandomierz.

Opportunities of spending free time are considered generally as sufficient (44\%) and not satisfactory (30\%). However $22 \%$ think that it is good. Only $4 \%$ of marks were very good. Employees of the administration assessed the opportunities of spending free time more favourably. In this group, the percentage of very good marks was around $8 \%$, whereas good ones was almost $32 \%$. The proportion of not satisfactory marks among administration workers was only between $10-14 \%$.

In the research, the attractiveness of Staszów and several other county towns of Świętokrzyskie Voivodeship was compared. Staszów was confronted with Busko Zdrój, Jędrzejów, Opatów, Pińczów and Sandomierz. The results occurred to be very interesting. According to the respondents, the most attractive in terms of tourism, is Sandomierz, which received the average mark of 4.8. The second was Busko Zdrój with the average much lower (3.7). The next were Opatów (3.4) and Pińczów (3.1).

Basically Staszów tourist attractiveness was, according to the respondents, the lowest with the average mark of 3.0.

Only in the group of Staszów Forest District Office workers, Jędrzejów and Pińczów got a lower mark for the tourist attractiveness than Staszów. According to the employees of the District Office, only Sandomierz and Busko Zdrój are more attractive in terms of tourism than Staszów. It needs to be clearly emphasized that these were mostly young people, less than 20 years old, that were most critical. Taking only this group into consideration, Staszów received the average mark of only 2.7. At the same time, the attractiveness of the other towns was not as low.

According to the people who took part in the survey, there will not be a considerable increase in the number of tourists visiting the area in the future (60\%). However $25 \%$ claim that the number will rise. $15 \%$ of the residents do not have any opinion on the subject. The main factors which slow the development of tourism are poor quality roads and generally poor communication. Another factor, which may be a barrier to the development of tourism, is insufficient promotional strategy of the town as well as poor attention and care being paid to the environment and monuments. The respondents also point out that the Town Council does not assign enough financial resources for tourism. 
3. General characteristics of the people who participated in the survey.

People who participated in the survey, characterised their attitude towards tourists as generally "positive" (68\%) and "very positive" $(18 \%)$. Only $3 \%$ assessed their attitude as "negative". However, $11 \%$ responded that they are unable to assess their attitude towards tourists. Clearly a higher percentage of people with a "very positive" attitude was observed in the group of people directly or indirectly connected with tourism sector.

$64 \%$ of women and $36 \%$ of men took part in the survey. The disproportion of gender was connected with the fact that women were more willing to take part in the survey. Slightly more women working in offices took part in the survey. 51\% defined their education as "higher", $34 \%$-"secondary" and 15\% - "primary".

$47 \%$ were people at the age of $21-40$, whereas $35 \%$ at the age of $41-60.12 \%$ claimed that they are below 20 , and $6 \%$ over 60 years old.

\section{Conclusions:}

The results of the research clearly indicate that effort should be made to improve the image of the attractiveness of the town and its surrounding areas, also according to the local residents. The positive attitude of the inhabitants of the mentioned area has a great importance in creating a tourist product and its quality. According to Niezgoda (2011), with reference to a tourist product, expectations of local residents should be equally important as those of visitors.

It seems that raising ecological awareness as well as the basic and general knowledge about the town and the region, are of great importance. It is difficult to expect better marks for the town of Staszów because of not sufficient tourist information about the places which may be of interest for tourists. What is more, many potentially interesting places lack proper maintenance and development as well as basic informative and educational setting.

The fact that the local residents mentioned the Church of St. Bartłomiej and the Town Hall with the town square (ph. 3 i 4) as the only tourist attractions in Staszów, clearly indicates that it is indispensable to take actions which will properly expose places which may be attractive in terms of tourism. Undoubtedly, gypsum outcrop of rocks in Staszów may become one. There is a small cave inside, which is an interesting example and the effect of karsting processes, which significantly influence the unique character of the region. Lajba Lake (currently neglected) and its surrounding (ph. 2) may also be an intriguing place to visit. However, information signs must be placed there which would draw attention, to those who are interested, to the origin, parametres and transformations of the lake and its surrounding. The lake is of karst origin. Currently, its depth is small $-4.3 \mathrm{~m}$, but in the past it was four times deeper. In the close proximity to the lake there is an area of peatland, dried through drainage, whose depth may, at places, reach $4 \mathrm{~m}$. It is a wonderful source of information about the past.

Furthermore, it is widely acknowledged that elements of the town's interesting history (e.g. pipes "Stambułki staszowskie" - the most popular product of the craftsmen from Staszów in the XVIII and XIX; highly valued "Staszówki" sabers) are not sufficiently used in the promotion of the region. 
It also needs to be mentioned that the assessment of the attractiveness of the town and its closest region by the administration workers is significantly different from the one given by the rest of the respondents. Some of them may not notice the problems, even ignore or underestimate them, assessing the town from the perspective of the effects of their own professional activities.

\section{LIST OF REFERENCES}

1. Niezgoda A., 2011: Town's attractiveness as an area of tourist reception according to the local residents' opinion - on the example of Poznań, [in:] Andrzej Rapacz (ed.) Tourism industry in the region. Business. Local government. Co-operation, Scientific Works of Wrocław University of Economics nr 157, Wyd. UE in Wrocław, pp. 845-856. (in Polish)

2. Zieliński A., 2012, Palace Complex in Kurozwęki as a tourist product of supra-regional importance, [in:] Jacek Buko (ed.) Tourist demand, European funds, regional issues, Scientific Fascicles of the University of Szczecin Nr 700, Economic problems of services nr 85, Szczecin, pp. 305-321. (in Polish)

3. Zieliński A., 2011a: Assessment of tourist traffic in Staszów region (South-eastern part of Świętokrzyskie Voivodeship). [in:] Andrzej Rapacz (ed.) Tourist industry in the region. Problems of its functioning. Wrocław University of Economics, Wyd. AD REM, Jelenia Góra, pp. 121-130. (in Polish)

4. Zieliński A., 2011b: The origin of floating islands on the lakes in Golejowskie Forests near Staszów. [in:] Peatlands in the transformed landscape- existence and protection. Scientific Workshops, Department of Quaternary Research, WNG University of Łódź; Department of Conservation, WBiOŚ University of Łódź; Geology Laboratory WNG University of Łódź; Foundation of the University of Łódź, Wawrzykowizna 1-3 June 2011, pp. 100. (in Polish)

5. Zieliński A. 2010a. Karst sink-holes in Golejowskie Forests as natural phenomenon of the north-eastern part of Połaniecka Basin. [in:] M. Ludwikowska-Kędzia, A. Zieliński red. Interdisciplinary Research - the past, the presence and the future of natural sciences. 1516.04.2010. Golejów near Staszów. Institute of Geography UJK in Kielce. Kielce, pp. 146151.

6. Zieliński A., 2010b. In the region of mid-forest lakes in the north-eastern part of Nidziańska Basin [in:] A. Predygier (ed.) X Kielce Science Festival, 15-30.09.2009. Wydawnictwo UJK, Kielce, pp. 80-84. (in Polish)

7. Zieliński A., 2010. The relation between landscape and development of tourism in the region of Staszów. [in:] Landscape vs. tourism. The works of The Cultural Landscape Commission No 14, The Cultural Landscape Commission PTG, Sosnowiec, pp. 274-283. (in Polish)

8. Zieliński A., 2007a: The Świętokrzyskie Province seen by geographers. [in:] Strzyż M., Zieliński A. (ed.), Region in the Education of Geography and Natural Sciences, Institute of Geography of Akademia Świętokrzyska, Geography Sciences in the regional research, vol. IV, Kielce, pp. 209-215. (in Polish)

9. Zieliński A., 2007b, Natural assets of the ecosystems of little karst lakes near Staszów [in:] Strzyż M., Świercz A., (ed.), Regional Studiem - Chosen Problems, Geography in the Regional Studies, Vol. III, Institute of Geography of Akademia Świętokrzyska, Kielce Branch of PTG, Kielce pp. 259-262. (in Polish) 


\title{
ТУРИСТИЧНА ПРИВАБЛИВІСТЬ СТАШОВА ВІДПОВІДНО ДО ЙОГО ЖИТЕЛІВ
}

\author{
А. Зелінський \\ Університет Яна Кохановського в м. Кельие \\ Кельие, Польща
}

У роботі проведена оцінка туристичної привабливості міста Сташів. Місто розташоване в південно-східній частині воєводства Свєнтокшицького воєводства, в області Полянецького карстового басейну, який являє собою субрегіон Ніджянського басейну. Аналіз був заснований на анонімному опитуванні репрезентативної групи з місцевих жителів.

Ключові слова: туристична привабливість, карстові озера, карстовий бассейн, туризм.

\section{ТУРИСТИЧЕСКАЯ ПРИВЛЕКАТЕЛЬНОСТЬ СТАШОВА СОГЛАСНО МНЕНИЮ ЕГО ЖИТЕЛЕЙ}

\author{
А. Зелинский \\ Университет Яна Кохановского в г. Кельие \\ Кельие, Польша
}

В работе проведена оценка туристической привлекательности города сташа. Город расположен в юго-восточной части воеводства Свентокшицького воеводства, в области Полянецкого карстового бассейна, который представляет собой субрегион Ниджянського бассейна. Анализ был основан на анонимном опросе репрезентативной группы из местных жителей.

Ключевые слова: туристическая привлекательность, карстовые озера, карстовый бассейн, туризм. 